\title{
Colon or Rectum Neuroendocrine Tumor Pathologic Regional Lymph Nodes TNM
} Finding $v 7$

National Cancer Institute

\section{Source}

National Cancer Institute. Colon or Rectum Neuroendocrine Tumor Pathologic Regional Lymph Nodes TNM Finding v7. NCI Thesaurus. Code C90109.

A pathologic finding about one or more characteristics of colon or rectum neuroendocrine tumor, following the rules of the TNM AJCC v7 classification system as they pertain to staging of regional lymph nodes. 